\title{
Particle size distribution of fly ash from co- incineration of bituminous coal with municipal solid waste
}

\author{
Ewelina Cieślik ${ }^{1 *}$, Tomasz Konieczny $y^{1}$ and Bartłomiej Bobik ${ }^{1}$ \\ ${ }^{1}$ Polish Academy of Sciences, Institute of Environmental Engineering, M. Skłodowskiej-Curie 34, \\ 41-819 Zabrze, Poland
}

\begin{abstract}
One of the source of air pollutants is emission from local coalfired boiler-houses and domestic heating boilers. The consequence of incineration of municipal waste is the introduction of additional pollutants into the atmosphere, including fly ash. The aim of this work was to evaluate the particle size distribution of fly ash emitted by coal combustion and co-incineration of coal with municipal waste in a domestic $18 \mathrm{~kW}$ central heating boiler equipped with an automatic fuel feeder. Mixtures of bituminous coal with different types of solid waste $(5,10$ and $15 \%$ of mass fraction) were used. Solid waste types consisted of: printed, colored PE caps, fragmented cable trunking, fragmented car gaskets and shredded tires from trucks. During the incineration of a given mixture of municipal waste with bituminous coal, the velocity of exhaust gas was specified, the concentration and mass flow of fly ash were determined together with the physico-chemical parameters of the exhaust gas, the samples of emitted fly ash were taken as the test material. Particle size analysis of fly ash was performed using laser particle sizer Fritch Analysette 22. The PM10 share from all fly ashes from incineration of mixtures was about $100 \%$. Differences were noted between PM2.5 and PM1.
\end{abstract}

\section{Introduction}

One source of air pollutants is the emission from local coal-fired boiler-houses and domestic heating boilers. About $37 \%$ of households in Poland are heated with singlefunction or combi solid-fuel boilers [1].

The use of feeders in boilers with permanent grates provides better fuel combustion conditions, but does not prevent the emission of harmful substances. The construction of such boilers allows them to incinerate solid waste, combustion of which is prohibited in Poland in boilers unsuitable for this purpose. During combustion in these boilers, the resulting gases are introduced into the atmosphere without purification, providing a major source of harmful emissions (including PM10 and PM2.5) [2].

\footnotetext{
*Corresponding author: ewelina.cieslik@ipis.zabrze.pl
} 
Solid particles are considered hazardous pollutants because they can be small enough to deposit deep in the lungs and cause respiratory and cardiovascular problems. The most dangerous particulate matter is dust with dimensions not exceeding $2.5 \mu \mathrm{m}$ [2].

The tests were carried out in a boiler actually used in central heating systems in small buildings, which, unlike physical or mathematical models, allows for an accurate assessment of the effects of fuel combustion in such boilers.

Research on the emission of gaseous and particulate pollutants by waste incineration in open spaces [3-5] and in laboratory conditions [6-9] has been carried out. Emissions from coal combustion [10], waste paper [11-12], polyethylene (PE) [13-15], polyvinyl chloride (PCV) [13-14], tires [3, 12 and 16] were determined. The studies were conducted for incineration of particular solid wastes. The impact of their co-incineration with coal has not been studied so far, as well as their incineration in domestic boilers equipped with an automatic dispenser and a fuel feeder.

The aim of this work was to compare the fly ash emission and to analyze the particle size distribution of fly ash emitted by coal combustion and co-combustion of coal with municipal waste in a domestic central heating boiler of $18 \mathrm{~kW}$ equipped with an automatic fuel feeder.

\section{Materials and methods}

The following fuels were used in the comparative tests of co-incineration of bituminous coal with individual solid wastes (ethylene propylene diene monomer (EPDM), tires, waste paper, polyvinyl chloride, polyethylene):

- bituminous coal (grain size: 5-25 mm), from the Kazimierz Juliusz mine in Sosnowiec (coal);

- shredded, printed xerographic paper (waste paper);

- fragmented car gaskets (EPDM rubber);

- shredded tires from trucks (tires);

- colored caps from juice, water bottles etc. (PE);

- fragmented cable trunking (PVC).

The examined fuels were subjected to chemical and technical analysis, which included determination of ash and volatile substances. In the case of solid waste co-incineration, 3 mixtures were used which differed by the mass fraction of waste in the fuel. The mixtures were prepared by mixing the previously weighed coal and proper types of municipal solid waste in the appropriate weight ratios. The mixtures containing 5, 10 and $15 \%$ of waste were analyzed. Table 1 shows the calculated ash and volatile substances values for each mix used. Coal combustion and co-incineration took place in a $18 \mathrm{~kW}$ central heating boiler equipped with an automatic fuel feeder.

Research material - fly ash, was collected during eight-hour combustion cycles of a given mixture of municipal waste with bituminous coal using a measuring probe, from the flue gas directed to the chimney, under the operating conditions of the boiler with nominal load, with full control of fuel combustion parameters. During each combustion cycle, the qualitative and quantitative composition of the main gaseous pollutants $\left(\mathrm{NO}_{\mathrm{x}}, \mathrm{CO}, \mathrm{SO}_{2}\right)$ was continuously analyzed. The mass flow of fly ash in the exhaust gas was determined using the gravimetric method.

Samples of fly ash were subjected to granulometric analysis on PM10, PM2.5 and PM1 content. The results are shown in Table 2.

Particle size analysis of fly ash was performed using laser particle sizer Fritch Analysette 22. The analyzer is used for rapid and automatic particle size analysis of solids in suspension by laser diffraction. The range of operation of the analyzer varies from 0.16 
to $1160 \mu \mathrm{m}$. Analysette 22 uses the physical principle of electromagnetic wave scattering during particle size analysis after its delivery to the analyzer.

\section{Results and discussion}

The boiler with the fuel feeder works periodically with two alternating modes - operation (with air and fuel supply to the combustion chamber) and supervision (blower and fuel feeder switched off). This results in a gradual increase and decrease of pollutant concentrations, depending on the mode of operation of the device. Sampling of fly ash to determine the concentration of ash in the exhaust gas was carried out in one-hour periods throughout the measurement period. The results obtained were averaged.

The highest proportion of ash in the fuel was obtained from PVC incineration $(26.27 \%)$ and lowest from PE incineration (0.61\%). All municipal waste showed a higher proportion of volatile substances compared to coal. Waste paper, EPDM rubber, PVC and tires had a comparable level of volatile substances, ranging from 65 to $70 \%$, while PE had a higher share, up to $99 \%$. Table 1 shows the calculated ash and volatile substances values for each mix used.

Table 1. Content of ash and volatile substances in the used mixtures $(\% \mathrm{~m} / \mathrm{m})$.

\begin{tabular}{|c|c|c|c|c|c|c|c|c|c|}
\hline \multirow{2}{*}{$\begin{array}{c}\text { fuel/ } \\
\text { mixture }\end{array}$} & \multicolumn{3}{|c|}{ waste paper } & \multicolumn{3}{c|}{ EPDM } & \multicolumn{3}{c|}{ PVC } \\
\cline { 2 - 10 } & $\mathbf{5 \%}$ & $\mathbf{1 0 \%}$ & $\mathbf{1 5 \%}$ & $\mathbf{5 \%}$ & $\mathbf{1 0 \%}$ & $\mathbf{1 5 \%}$ & $\mathbf{5 \%}$ & $\mathbf{1 0 \%}$ & $\mathbf{1 5 \%}$ \\
\hline ash & 4.75 & 5.50 & 6.25 & 4.24 & 4.36 & 4.61 & 5.11 & 6,23 & 7,34 \\
\hline volatile substances & 32.64 & 34.61 & 36.59 & 34.1 & 35.82 & 39.26 & 32.38 & 34,1 & 35,81 \\
\hline $\begin{array}{c}\text { fuel/ } \\
\text { mixture }\end{array}$ & \multicolumn{3}{|c|}{ PE } & \multicolumn{3}{c|}{ tires } & \multicolumn{3}{c|}{ coal } \\
\cline { 2 - 10 } & $\mathbf{5 \%}$ & $\mathbf{1 0 \%}$ & $\mathbf{1 5 \%}$ & $\mathbf{5 \%}$ & $\mathbf{1 0 \%}$ & $\mathbf{1 5 \%}$ & \multicolumn{3}{|c|}{$\mathbf{1 0 0 \%}$} \\
\hline ash & 3.83 & 3.66 & 3.49 & 4.12 & 4.24 & 4.35 & 4.00 \\
\hline volatile substances & 34.09 & 37.53 & 40.96 & 32.44 & 34.21 & 35.99 & 30.66 \\
\hline
\end{tabular}

Table 2 shows the calculated dust emission rates per unit of fuel and the estimated share of PM1, PM2.5 and PM10 in the fly ashes collected.

Table 2. Fly ash emission factor $\left(\mathrm{g} / \mathrm{kg}_{\text {fuel }}\right)$ and PM1, PM2.5 and PM10 share in fly ashes (\%).

\begin{tabular}{|c|c|c|c|c|c|c|c|c|c|}
\hline \multirow{2}{*}{$\begin{array}{c}\text { fuel/ } \\
\text { mixture }\end{array}$} & \multicolumn{3}{|c|}{ waste paper } & \multicolumn{3}{|c|}{ EPDM } & \multicolumn{3}{|c|}{ PVC } \\
\hline & $5 \%$ & $10 \%$ & $15 \%$ & $5 \%$ & $10 \%$ & $15 \%$ & $5 \%$ & $10 \%$ & $15 \%$ \\
\hline $\mathbf{E F}_{\text {ash }}$ & 2.58 & 1.50 & 1.86 & 3.89 & 5.01 & 7.38 & 4.05 & 5,93 & 7,44 \\
\hline PM1 & 50.8 & 50.4 & 50.9 & 43.5 & 37.8 & 44.1 & 33.4 & 36,8 & 46,1 \\
\hline PM2.5 & 87.1 & 86.1 & 87.1 & 74.8 & 62.1 & 68.6 & 63.9 & 68,0 & 78,7 \\
\hline PM10 & 100 & 100 & 100 & 100 & 99.3 & 100 & 99.9 & 99,9 & 99,9 \\
\hline \multirow{2}{*}{$\begin{array}{c}\text { fuel/ } \\
\text { mixture }\end{array}$} & \multicolumn{3}{|c|}{ PE } & \multicolumn{3}{|c|}{ tires } & \multicolumn{3}{|c|}{ coal } \\
\hline & $5 \%$ & $10 \%$ & $15 \%$ & $5 \%$ & $10 \%$ & $15 \%$ & \multicolumn{3}{|c|}{$100 \%$} \\
\hline $\mathbf{E F}_{\text {ash }}$ & 3.43 & 4.25 & 4.51 & 1.65 & 1.96 & 3.57 & \multicolumn{3}{|c|}{3.61} \\
\hline PM1 & 40.1 & 42.1 & 37.7 & 42.3 & 48.4 & 26.9 & \multicolumn{3}{|c|}{42.9} \\
\hline PM2.5 & 83.0 & 81.5 & 76.7 & 67.0 & 72.1 & 63.4 & \multicolumn{3}{|c|}{75.3} \\
\hline PM10 & 100 & 100 & 100 & 100 & 100 & 98.7 & \multicolumn{3}{|c|}{100} \\
\hline
\end{tabular}


The fly ash emission was lowest in the co-incineration of coal with waste paper and coal with tires (mean values of 2.0 and $2.4 \mathrm{~g} / \mathrm{kg}_{\text {fuel }}$ respectively). It was lower than the corresponding rate in the case of coal combustion, which amounted to $3.6 \mathrm{~g} / \mathrm{kg}_{\text {fuel }}$. During EPDM rubber, PE and PVC co-incineration, the fly ash emission figures were higher (mean values of $5.4,4.1$ and $5.8 \mathrm{~g} / \mathrm{kg}$ respectively). The fly ash emissions obtained from the coincineration of the waste are on average seven times lower than in the case of incineration of clean waste under laboratory and open burning conditions [8-9]. The dust emission values obtained from co-incineration of PVC and PE mixtures are not compatible with the literature data. Incineration of these wastes in laboratory conditions caused lower emission in the case of PVC and higher in the case of PE [6].

The particle size distribution of fly ash from coal combustion, PVC and tires mixtures is shown in Fig. 1 - 3. According to literature data, the bulk equivalence ratio has an influence on particle size distribution of fly ash [6].

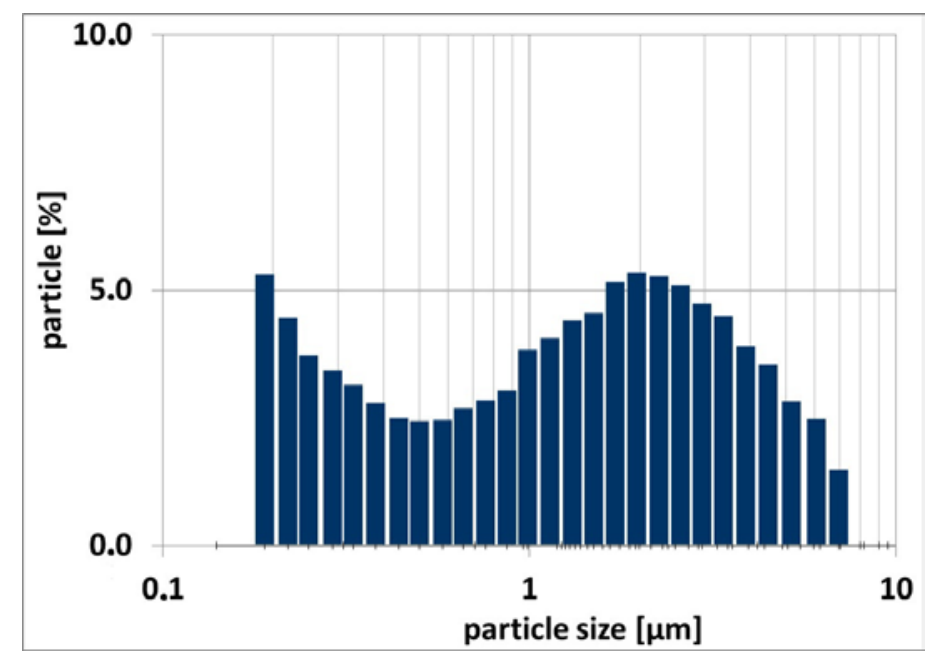

Fig. 1. Particle size distribution of fly ashes from coal combustion.

PM10's share in all fly ash from mixtures' incineration was about $100 \%$. Differences in the PM2.5 fraction were noted. Fly ash from co-incineration of waste paper and PE was characterized by the highest content of PM2.5 (86.8 and 80.4\%, respectively). In the case of co-inicineration of EPDM rubber, tires and PVC, PM2.5 fraction share was lower than from coal combustion $(75.3 \%)$ and equaled to $68.5,67.5$ and $70.2 \%$, respectively. According to literature, $\mathrm{PVC}$ combustion is associated with the highest share of particles above $2 \mu \mathrm{m}$ [6].

In the case of PVC co-incineration, the share of PM2.5 in fly ash increased with the increase of the mass fraction of waste in the mix, whereas in the case of PE co-incineration an opposite was observed - the increase of the waste content in the mix reduced the PM2.5 share in fly ash.

The granulometric composition of fly ash obtained from mixtures containing 5 and $10 \%$ of tires was similar. Large differences were noted in the combustion of the mixture containing $15 \%$ of tires, as shown in Fig. 3. The PM1 content in fly ash from this mixture was the lowest and was about $27 \%$. Differences have also been observed in fly ash from the combustion of a mixture containing $15 \%$ of PVC in relation to mixtures containing 5 and $10 \%$ of this waste (Fig. 2). This ash was characterized by a higher proportion of PM1 and PM2.5 than fly ash from combustion of other mixtures of this waste. 


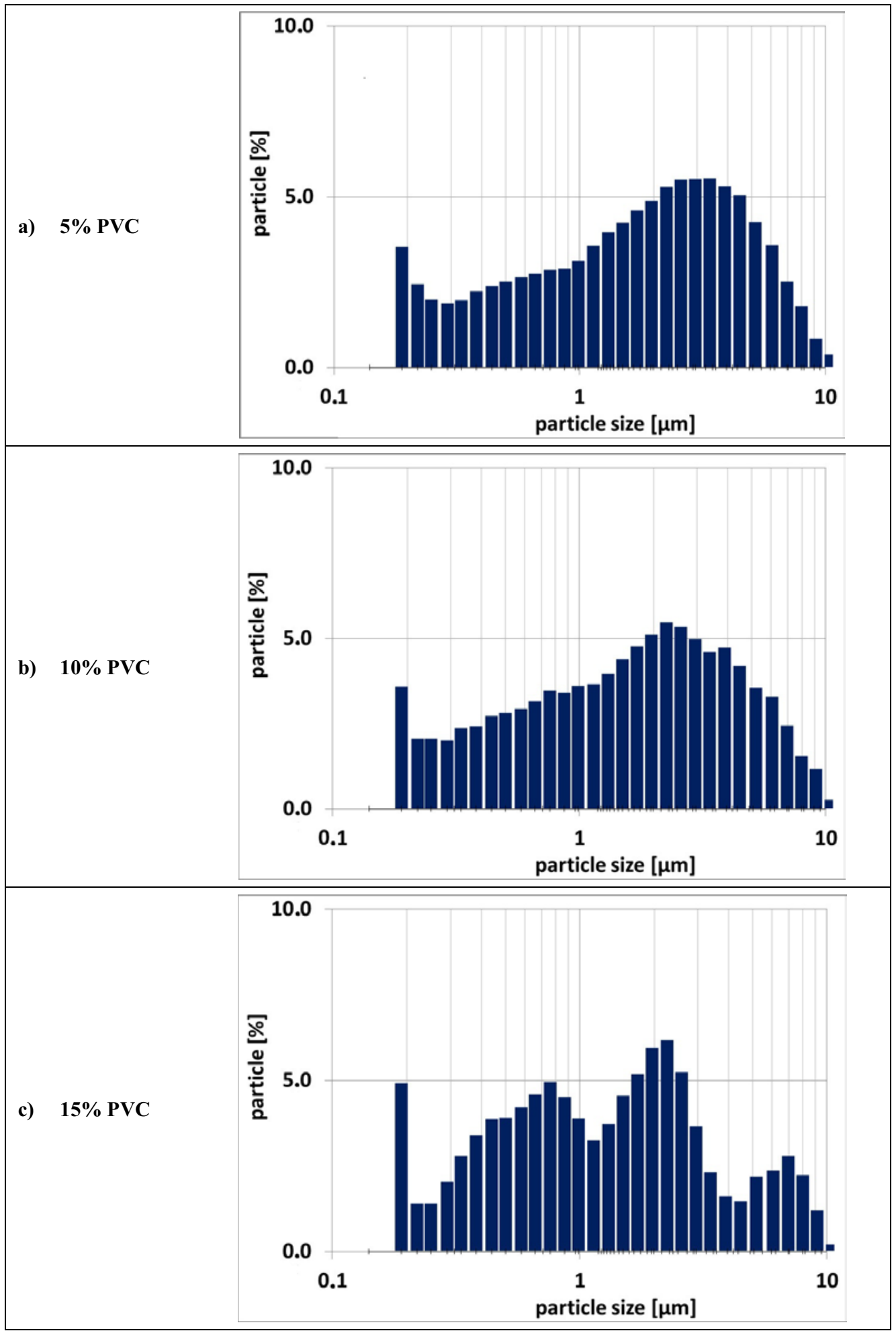

Fig. 2. Particle size distribution of fly ashes from co-incineration of coal with PVC. 
a) $5 \%$ of tires

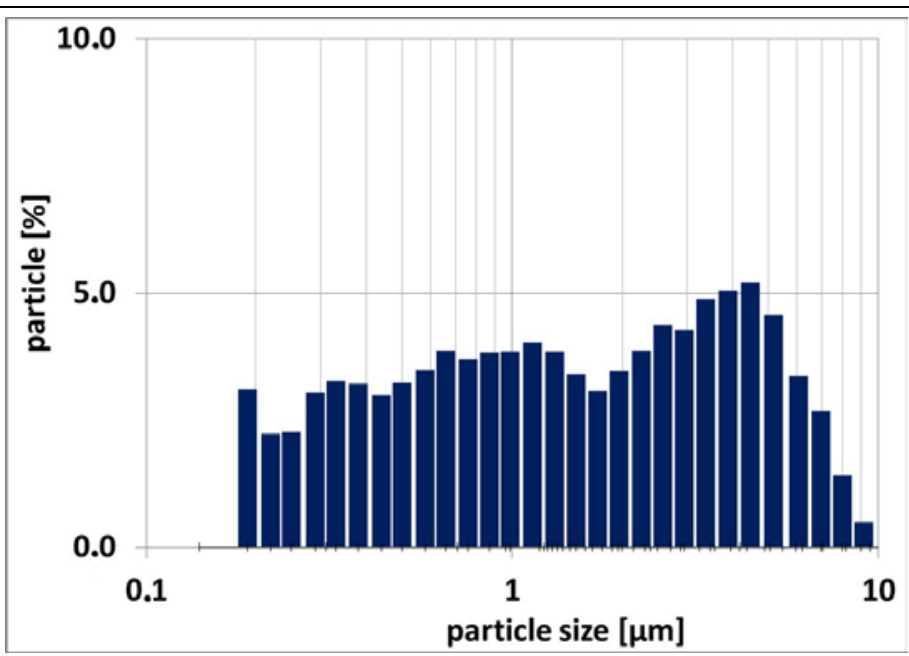

b) $10 \%$ of tires

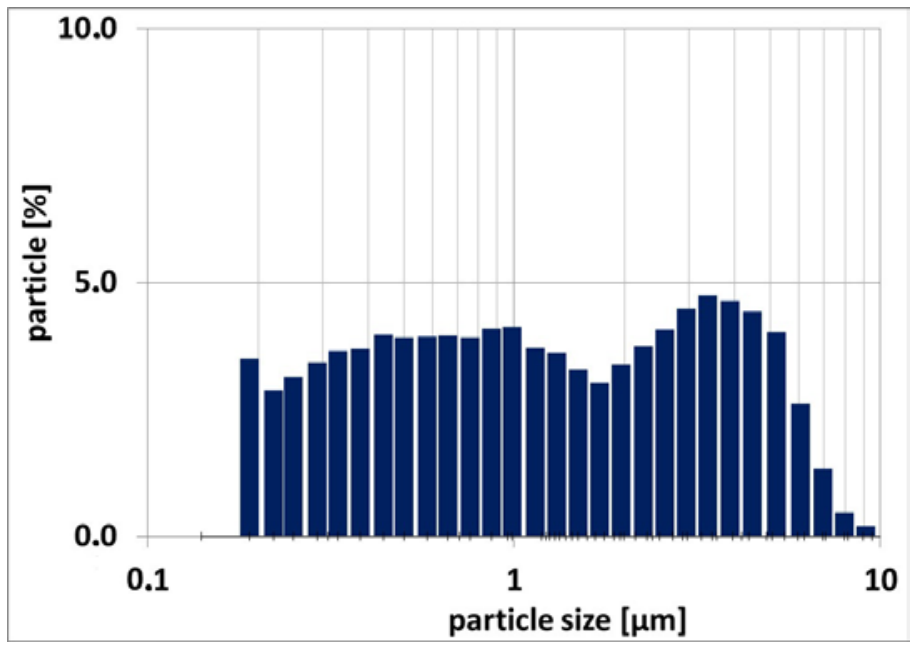

c) $15 \%$ of tires

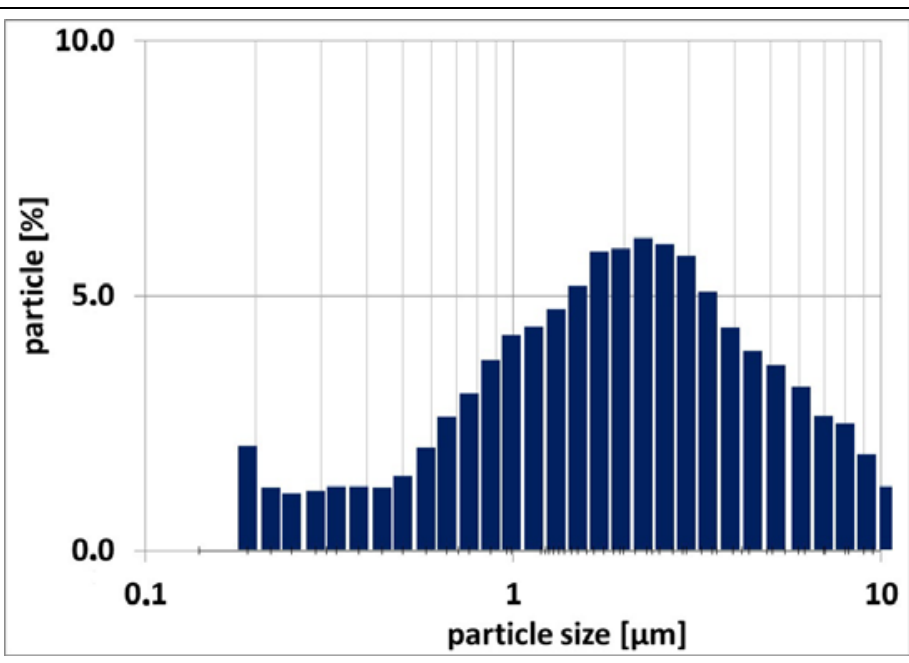

Fig. 3. Particle size distribution of fly ashes from co-incineration of coal with tires. 
During the co-incineration of waste paper, the mass increase of waste did not contribute to the change of PM2.5 share in the samples tested. Analysis of the measurement results for EPDM rubber and tire co-incineration showed no correlation.

The PM2.5 and PM1 share in fly ash from coal combustion was lower than the data available in the literature for domestic heating boilers, which is related to the construction of the heating device used and the removal of larger particles while flue gas passes through the baffles in the boiler.

\section{Summary}

Small solid-fuel boilers emit fly ash with a high share of fine particles. Emission of fly ash from coal combustion equaled 3.6 and from coal co-incineration with municipal waste it ranged from 1.5 to $5.9 \mathrm{~g} / \mathrm{kg}_{\text {fuel }}$ and was lower than in the case of waste incineration under laboratory conditions.

The PM10 share in the fly ash from the incineration of the mixtures was about $100 \%$. Differences were noted between PM2.5 and PM1.

The PM10 share in fly ash was over $98 \%$ of emitted dust. The share of PM2.5 ranged between 62-82\%, while PM1 varied between 27 and 51\%.

The fly ash from the co-incineration of waste paper was characterized by the highest content of PM1 fraction (50.4\%) and together with fly ash from PE co-incineration was characterized by the highest content of PM2.5 fraction $(86.7 \%$ for waste paper and $80.4 \%$ for PE).

In the case of PVC co-incineration, the share of PM2.5 and PM1 in fly ash increased with the increase of the mass fraction of waste in the mix, whereas in the case of PE coincineration an opposite was observed - the increase of the waste content in the mix reduced the PM2.5 and PM1 share in fly ash.

The project has been financed by National Science Centre in Poland under the project no. DEC2013/11/N/ST10/00995.

\section{References}

1. CSO Energy consumption in households in 2015. Warszawa 2017

2. K. Juda-Rezler and B. Toczko, Eds., Pyty drobne w atmosferze. Kompendium wiedzy o zanieczyszczeniu powietrza pyłem zawieszonym w Polsce. Warszawa: Głowny Inspektorat Ochrony Środowiska (2016)

3. A. Lönnermark, P. Blomqvist, S. Marklund, Chemosphere, 70, 626 (2008)

4. S. Sidhu, B. Gullett, R. Striebich, J. Klosterman, J. Contreras, M. DeVito, Atmos. Environ., 39, 801 (2005)

5. T.J. Christian, R.J. Yokelson, B. C'ardenas, L.T. Molina, G. Engling, S.-C. Hsu, Atmos. Chem. Phys., 10, 565 (2010)

6. B.E. Shemwell, Y.A. Levendis, J Air Waste Manag Assoc., 50, 94 (2000)

7. T. Nakao, O. Aozasa, S. Ohta, H. Miyata, Chemosphere, 62, 459 (2006)

8. A. Lönnermark, P. Blomqvist, Emissions from Tyre Fires, SP Fire Technology, SP REPORT, 43 (2005)

9. F. Reisen, Inventory of major materials present in and around houses and their combustion emission products, Report to Bushfire CRC, (2011) 
10. A.B. Ross, J.M. Jones, S. Chaiklangmuang, M. Pourkashanian, A. Williams, K. Kubica, J.T. Andersson, M. Kerst, P. Danihelka, K.D. Bartle, Fuel, 81, 571 (2002)

11. J.S. Choi, D.K. Lee, K.H. Kim, Y.M. Jo, Evaluation of Emission Factor of Harmful Elements from Open Burning, (ISWA/APESB World Congress 2009, Lisbon 2009)

12. J.A. Conesa, R. Font, A. Fullana, I. Martín-Gullón, I. Aracil, A. Gálvez, J. Moltó, M.F. Gómez-Rico, J. Anal. Appl. Pyrolysis, 84, 95 (2009)

13. A. Valavanidis, N. Iliopoulos, G. Gotsis, K. Fiotakis, J. Hazard. Mater., 156, 277 (2008)

14. T. Panagiotou, Y.A. Levendis, J. Carlson, P. Vouros, Symp. (Int.) Combust., 26, 2421 (1996)

15. B.R.T. Simoneit, P.M. Medeiros, B.M. Didyk, Environ. Sci. Technol., 39, 6961 (2005)

16. P.M. Lemieux, Ch.C. Lutes, D.A. Santoianni, Prog. Energy. Combust. Sci., 30, 1 (2004) 